\title{
脳室内および脳室近傍腫掦摘出に必要な内視鏡手術解剖
}

\author{
渡邊 督 ${ }^{1}$, 永谷 哲也 ${ }^{2}$, 齋藤 清 ${ }^{3)}$ \\ 1）名古屋第二赤十字病院脳神経外科，2）名古屋大学大学院脳神経外科，3）福島県立医科大学脳神経外科
}

\section{Endoscopic Anatomy of Cerebral Ventricles}

\author{
Tadashi Watanabe, M.D. ${ }^{1)}$, Tetsuya Nagatani, M.D. ${ }^{2}$, and Kiyoshi Saito, M.D. ${ }^{3)}$
}

1) Department of Neurosurgery, Nagoya Daini Red Cross Hospital, 2) Department of Neurosurgery, Nagoya University Graduate School of Medicine, 3) Department of Neurosurgery, Fukushima Medical University

Endoscopic approaches to intraventriclar lesions and the endoscopic anatomy of the cerebral ventricles are described. A wide visual field, close observation for deep seated lesions and exploration in the wet field are the benefits of endoscopic surgery. In addition, changes in view point help to foster a better understanding of the three-demensional anatomy of the cerebral ventricles. Endoscopic tumor removal is performed via various types of transparent sheathes with specially designed instruments. The ventricles are surrounded by essential structures, which should be kept intact during the surgery. Distortion of the paraventricular structures is often seen in patients with paraventricular tumors. The foramen of Monro, choroid plexus, and thalamostriate vein are the clear landmarks to follow even in distorted anatomy. Understanding the endoscopic anatomy of the cerebral ventricles based on these landmarks assures a correct orientation and safety during the surgical treatment.

(Received December 4, 2012 ; accepted January 8, 2013)

Key words : endoscopic, cerebral ventricles, anatomy, brain tumor

Jpn J Neurosurg（Tokyo）22:340-348, 2013

\section{はじめに}

脳室は脳実質に囲まれており，治療で脳室へアクセス する場合は必ず何らかの脳の犠牲がある。内視鏡手術の 特徴は小さな入口からアクセスでき，明るく広い視野角 で深部病変を近接して観察できる点である。透明シース を用いることでさらに最大限の視野を得ることができ， 斜視鏡の使用も随時可能である。また，人工䯣液の持続 環流下の wet field での観察は内視鏡手術に限られた特 徵である。これらの特徵を生かし，シースを用いて最小 限の corridor で脳室にアクセスし, 脳室内病変の内視鏡 下生検，摘出を行う cylinder surgeryに取り組んでいる. Nishihara $ら^{6)}$ の血腫除去の報告ではシースの動きを利用
し血腫を除去し，シースを透明にすることによって視野 が広がり, 飛躍的に手術の環境が改善された。内視鏡下 にシースを介した脳内，脳室内腫瘍摘出術の報告もあ $3^{1) 2}$. シースのバリエーションが増え, 高画質の内視鏡 が登場し，内視鏡のホルダーを使用して，専用の器具を 使うことで両手操作による剝離，切開，凝固が可能にな り，腫瘍への応用が可能となった。

脳室の解剖は三次元的に特徴のある立体構造に加え， 動脈，静脈の走行，神経線維の走行，膜の構造などが複 雑に関係し合っており，すべてを理解するのが難しいと 筆者は感じている。発生のかなり早い段階から脳室は形 成され，原始脳に囲まれているのも，この複雑かつ，合 理的な構造を有する理由なのかもしれない，われわれに

連絡先：渡邊 督, $\bar{\top} 466-8650$ 名古屋市昭和区妙見町 2-9 名古屋第二赤十字病院脳神経外科

Address reprint requests to: Tadashi Watanabe, M.D., Department of Neurosurgery, Nagoya Daini Red Cross Hospital, 2-9 Myokencho, Showa-ku, Nagoya-shi, Aichi 466-8650, Japan 


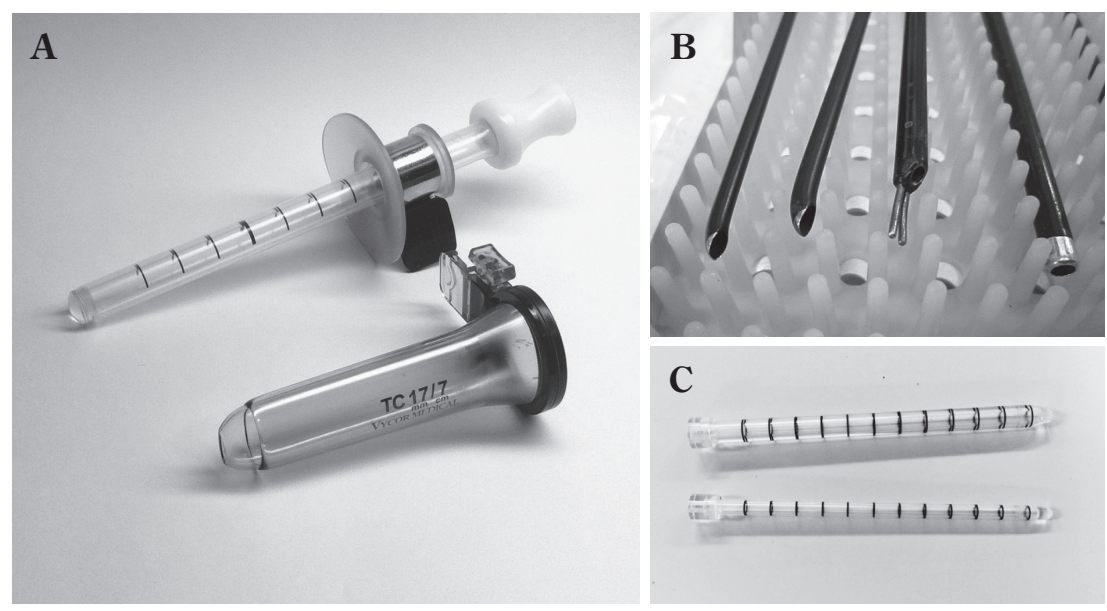

Fig. 1 A : Neuroport ${ }^{\mathrm{TM}}$ (Olympus, inner diameter $9 \mathrm{~mm}$ ) and VIEWSITE $^{\mathrm{TM}}$ (Vicor Medical, inner diameter $17 \mathrm{~mm} / 11 \mathrm{~mm}$ ).

B : Several suction coagulators.

C : Transparent test tap needle (Lower, outer diameter $5 \mathrm{~mm}$ ) and transparent dilator (Upper, outer diameter $8 \mathrm{~mm}$ ).

求められるのは，脳室経由での外科手術の際に必要な解 剖の知識を身につけることである。実際の手術では，脳 室壁は全体を上衣組織で覆われており，利用できるラン ドマークは限られている。 さらに腫瘍によりひずみが生 じると，しばしばオリエンテーションを失い病変の同定 が難しいことがある。脳室内の手術を安全に行うために は解剖学的ランドマークを基準に, 重要構造物の三次元 的位置関係を把握する必要がある。

本稿では，シース内の限られた術野での特殊な手術手 技と, 内視鏡観察下の脳室解剖について解説する.

\section{脳室内腫瘍に対する内視鏡手術の概要}

筆者の使用するシースは $17.5 \mathrm{Fr}$ のニューロシース ${ }^{\mathrm{TM}}$ (メディキット)，ニューロポート ${ }^{\mathrm{TM}} レ$ レ゙ュラー(オリン パス, 外径 $10 \mathrm{~mm}$, 内径 $9 \mathrm{~mm}$ ), VIEWSITE ${ }^{\mathrm{TM}} \mathrm{TC} 17 / 7$

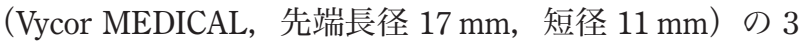
種類である。バイオプシー，第三脳室内腫瘍には主に ニューロシース ${ }^{\mathrm{TM}}$ を, 吸引除去主体の手術はニューロ ポート VIEWSITE ${ }^{\mathrm{TM}}$ を用いている (Fig. 1)。VIEWSITE ${ }^{\mathrm{TM}}$ は顕微 鏡手術用に開発されたチューブレトラクターであるが, 内視鏡手術においても有用である7 ${ }^{7}$.

適切なアクセスルートを術前に十分検討することが重 要で, 腫瘍の発生部位, 栄養血管の走行, 手術の目的な どを考慮し，バーホールの位置を決める。前角，体部， 第三脳室病変には頭部を正中位とし，前角穿刺を行う。
後角病変には，仰臥位で同側の肩を枕などで挙上し，頭 部を 90 度回転して後角穿刺を行う。症例によっては中 側頭回の皮質切開にて行う場合もある.

$4 \mathrm{~cm}$ の直線状の皮膚切開を加え, 骨膜を弧状切開し, $1.5 \mathrm{~cm}$ のバーホールを作成し, corticotomy を加えてシー スを挿入する. VIEWSITE ${ }^{\mathrm{TM}}$ を使用する場合は $3 \mathrm{~cm}$ の開 頭, $1.5 \mathrm{~cm}$ の corticotomy を行う。脳溝に穿刺が迷入し ないようにし，脳表の静脈は極力温存する．腫瘍の局在 を考慮して穿刺部位を決定する。特に正中付近からのア プローチを行う場合は重要な架橋静脈が直下に存在する 場合があるので注意が必要である，皮質切開はなるべく 脳回に沿って加え，径 $1 \mathrm{~cm}$ のシースであれば $1 \mathrm{~cm}$ ，長 径 $17 \mathrm{~mm}$ のシースであ机ば $15 \mathrm{~mm}$ の切開を行う。脳表 の動静脈をなるべく温存するように配慮した皮質切開を デザインする（Fig. 2)。ナビゲーションガイド下に方向 を定め, 内視鏡観察下に試作の透明穿刺針を使用して最 初の穿刺を行う (Fig. 1C). 外径 $5 \mathrm{~mm}$ 内径 $3 \mathrm{~mm}$ で, 2.7 $\mathrm{mm}$ の内視鏡で観察しながら挿入できるので，脳室への 到達，深さを確認できるとともに，髄液吸引や，洗浄な ぞ，手を加える前の状態の脳室，腫瘍を観察することが できる。その後 trajectoryに沿ってシースを挿入する。 なるべく脳実質の損傷を避けるために透明ダイレーター を用いる（Fig. 1C）。

腫瘍摘出術を行うには硬性鏡もしくは軟性鏡のワーキ ングチャンネルを介した操作では不十分である。硬性鏡 を用いたシース内手術では，手術道具と，内視鏡，シー スが独立した動きをとることが可能である。シースは術 

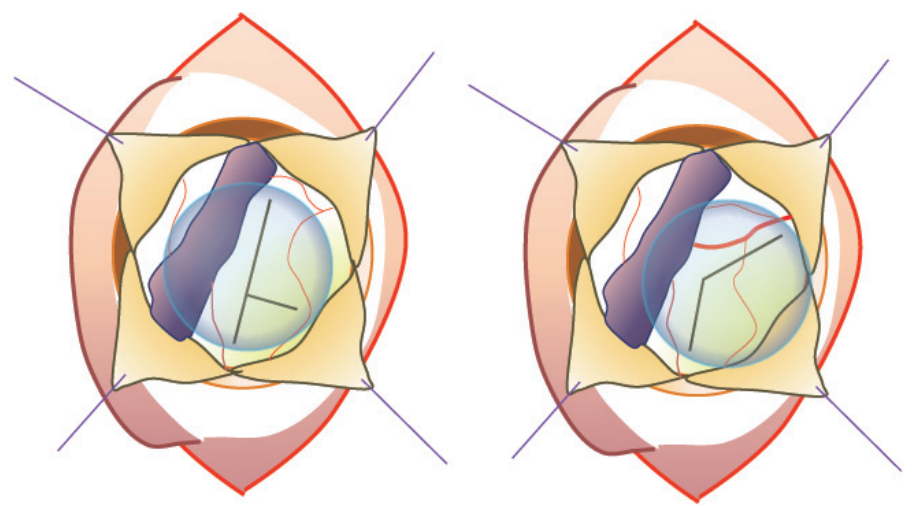

Fig. 2 Trephination Illustration

A linear skin incision and a curved periosteum incision are made. After making a $1.5 \mathrm{~cm}$ trephination, a crucial dural incision is made. About a $1 \mathrm{~cm}$ cortical incision is designed to spare the bridging vein or cortical arteries.

Left: A $T$ shape cortical incision is designed in the avascular area. Right: Curved cortical incision is made sparing relatively large vessels with minimum sacrifice of a tiny vessel.
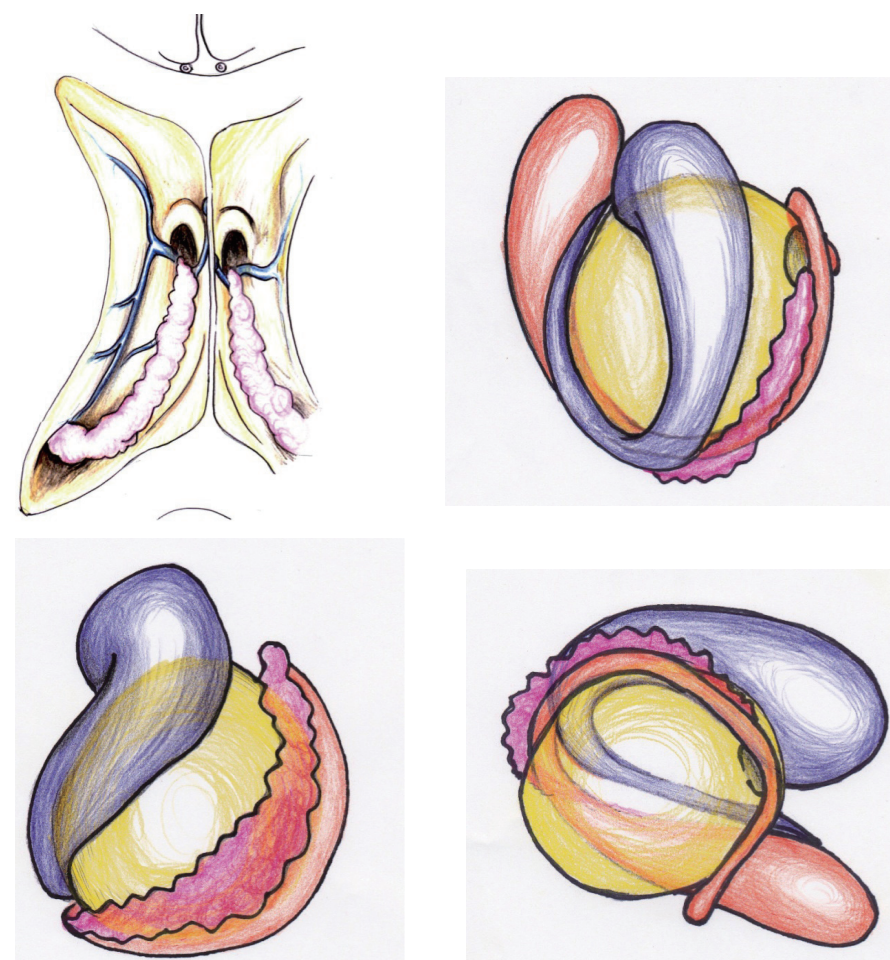

Fig. 3 Left upper illustration: Superior view of the lateral ventricles.

Illustrations show the relationship of the caudate nucleus (blue), thalamus (yellow), choroid plexus (pink), and fornix and hypocampal formation (Orange) of the left side.

Upper right; superior view, Lower left; posterior view, Lower right; medial view. 
A
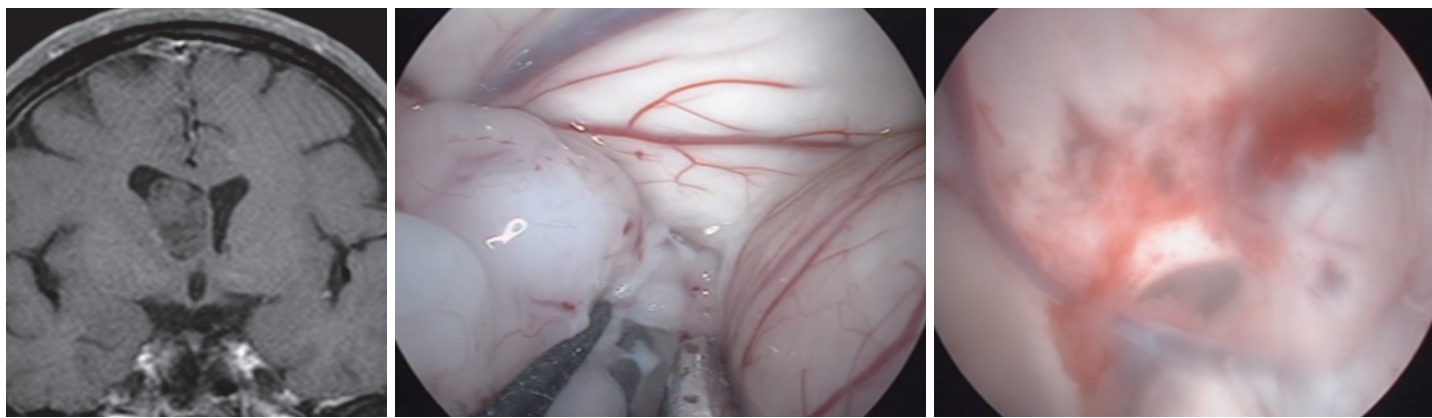

B

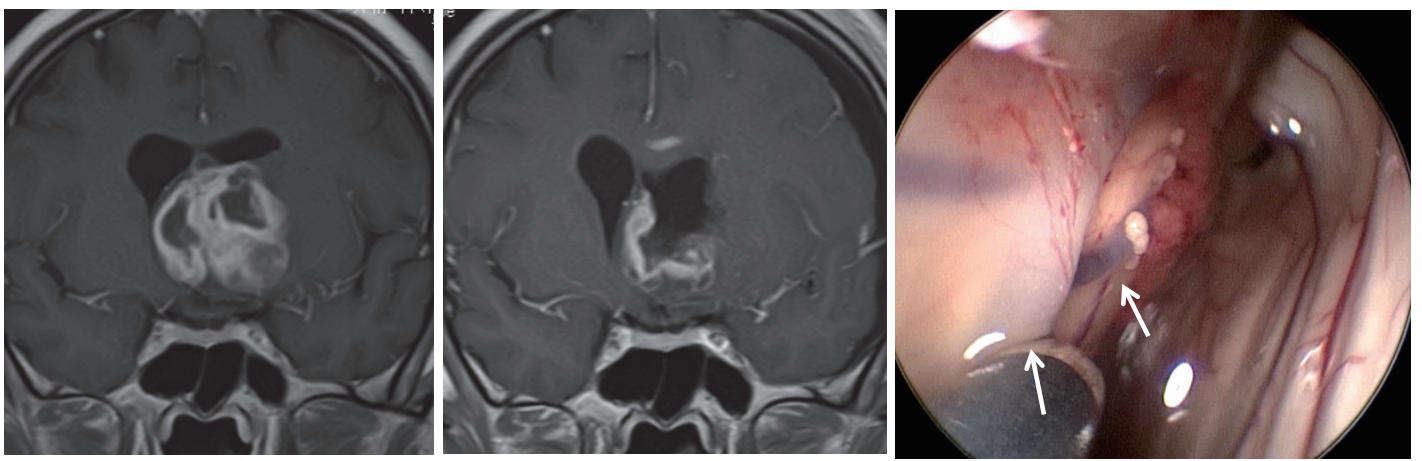

Fig. 4 A : Left; Coronal enhanced T1 image showing a tumor in the right frontal horn (subependymoma). Middle; The attachment of the tumor at the base of the frontal horn is dissected. Right; After total removal of the tumor, the foramen Monro, and thalamostriate vein are identified.

B : Left and Middle; Pre and post operative MRI showing a heterogeneously enhanced tumor in the left basal ganglia (glioma). Right; After left frontal horn puncture, the elevated floor of the lateral ventricle was observed. Two thalamostriate veins (arrows) and the choroid plexus were identified.

野を確保する役割があり,レトラクターとして使用する。 特に髄液を吸引除去しながら行う dry field の操作にお いては，脳室の空間が狭くなるため，操作中のシースの 役割が重要である。腫瘍の大きさ，性状，位置に合わせ て，シースを選ぶ。吸引可能な腫瘍，あるいは境界明瞭 で小さなものは細径のシースで対応可能である。第三脳 室内にモンロー孔経由でアプローチする場合は，17.5 Fr のニューロシースを用いる。これらの細径のシースを使 用する場合は, 内減圧が基本となるので, 吸引除去可能 な腫瘍が手術適応となる。側脳室腫瘍において内減圧, または剝離が困難と予測される場合は，現在使用できる 大きめのシース VIEWSITE ${ }^{\mathrm{TM}}$ を用いて two-hand surgery を行う。このシースを使う場合は, 顕微鏡手術道具 の使用も可能である。

細径のシース内で使用可能な器具は限られる。止血は 内視鏡下血腫除去に使用するモノポーラ凝固用吸引管を 使用する。凝固するポイントを接触させ，周辺組織は先 端に触れないようにし, さらに，血液や髄液を常に吸引 して dry field を保つことで有効な凝固ができる. 先端の
形状を工夫したり，バイポーラ付吸引管なども試作して いる (Fig. 1B).

Dry field と wet filed は適宜, 場面によって使い分ける 必要がある。前述のように凝固を断続的に行う場面や， 吸引管を動かしながら腫瘍を吸引除去する場面では dry field にて one-hand 操作を行う。ポイントを決めて, 出 血のある術野をクリアに保ち，切開や剝離を行う場合は dry field にて two-hand 操作を行う. $10 \mathrm{~mm}$ のシース内 で使用可能なバイポーラも使用している。脳室に人工髄 液を満たし，持続洗浄することで，脳室は膨らみ，術野 が得られ, wet field で脳室の全体的な観察が可能である. 出血がほとんどない術野では, 切開や䟝離操作は wet field の one-hand 操作が可能である. One-hand, twohand, dry field, wet field のテクニックを適宜使い分けて, 切開，吸引，剝離，凝固を行い目標を達成する.

\section{内視鏡脳室解剖}

脳室内の内視鏡による観察は，広い範囲を全体的に観 

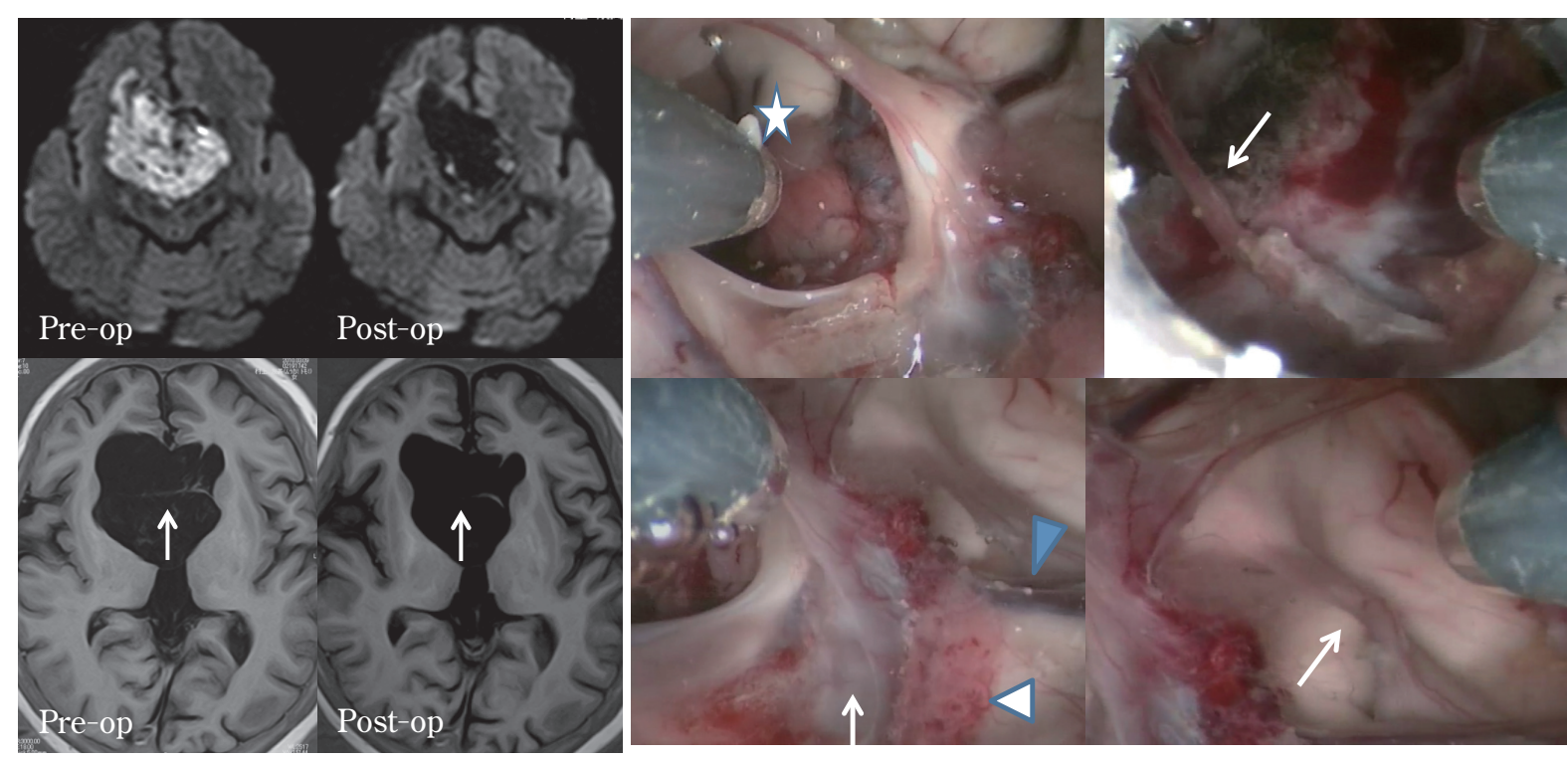

Fig. 5 A Case of recurrent teratoma. Right frontal horn puncture was performed with a transparent sheath. The structures near the foramen Monro were compressed inferoposteriorly by the slow growing tumor.

A : Upper; Pre and post operative diffusion weighted images. Lower; Pre and post operative MRI showing the presence of anterior commissure (arrows).

B : Upper left; Distorted structure of left foramen Monro (star). Right foramen Monro is extremely stretched along the edge of the tumor.

Upper right; The thin anterior commissure was identified in the tumor cavity after removal of the tumor contents (arrow).

Lower left; Thalamostriate vein (blue triangle) and choroid plexus (white triangle) at the foramen Monro are shifted posteriorly. Internal cerebral veins at the roof of the third ventricle are seen beneath the tela choroidea (arrow).

Lower right; The third ventricle was compressed posteriorly. The massa intermedia was identified (arrow).

察することができ，さらに内視鏡の動きにより視点が動 くため，立体的な把握が比較的しやすいと考えられる。

Dry field においては脳室が collapse し，観察が困難にな ることもあるが，人工髄液環流下の wet field において は，脳室の空間を維持しながら観察できる利点がある.

\section{側脳室概観}

側脳室全体をイメージする場合，視床を中心に考える と, 外側に尾状核, 内側に脳弓が視床に巻きついている. そして，常に脈絡叢は視床と脳弓の間にある。体部，後 角, 下角では 脳梁-尾状核-視床-脈絡叢-脳弓の順に並 んでおり，この順序は変わらない（Fig. 3)。脳弓は下角 では海馬となり, 脳梁は下角では tapetum となる。モン ロー孔は脳室解剖において最も重要で明確なランドマー クである，前角，体部の境界に位置し，第三脳室と側脳 室をつなぐ 1 対の孔であり, 前縁および上縁は脳弓, 後 縁には脈絡叢, 視床穿通静脈, 下緑は視床によって成り
立つ. 側脳室底は, 視床の丸みに沿ってカーブしており, モンロー孔は外側上前方に開いている。透明中隔下縁を 走っていた脈絡叢はモンロー孔で折り返し，第三脳室の 上壁に続く。

\section{前 角}

正中壁は後方で透明中隔，前壁は脳梁膝部，側壁は尾 状核，下壁は rostrum of corpus callosm にあたり，後方正 中側でモンロー孔前縁を形成する脳弓に至る。モンロー 孔より前方で透明中隔はなくなり， callosum genu があ り，底面は rostrum に移行する。 rostrum は前交連を経 て, lamina terminalis に移行する. rostrum は薄く, 損傷 により大脳間裂のくも膜下腔へ交通が得られる場合があ る. Subependymoma, central neurocytoma, subependymal giant cell astrocytoma などでは，しばしばモンロー孔付 近で付着部を認める。Thalamostriate vein などの重要な 静脈が集まる部位なので，損傷しないように注意する。 
A

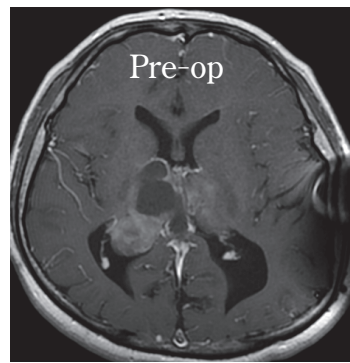

B

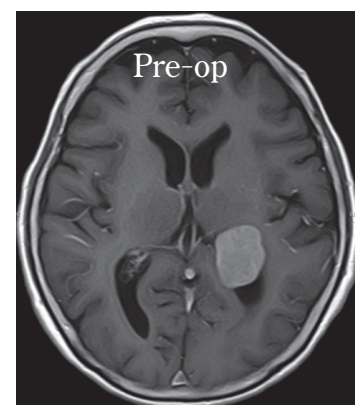

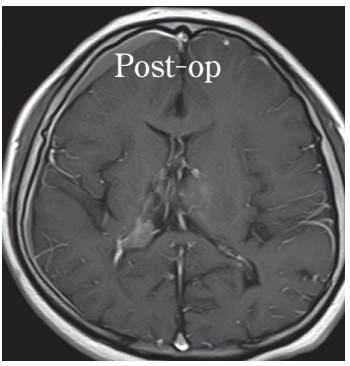
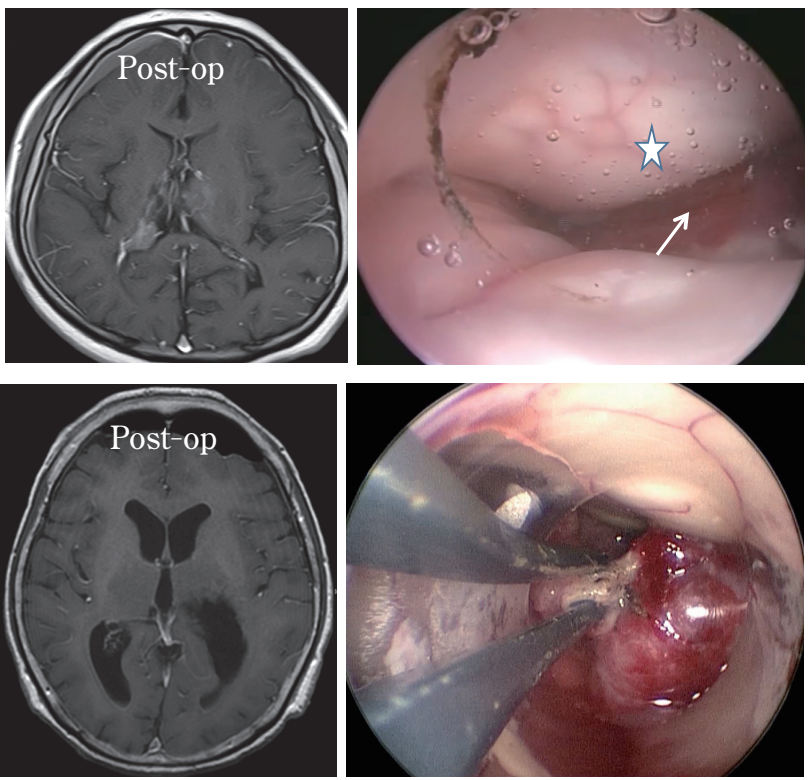

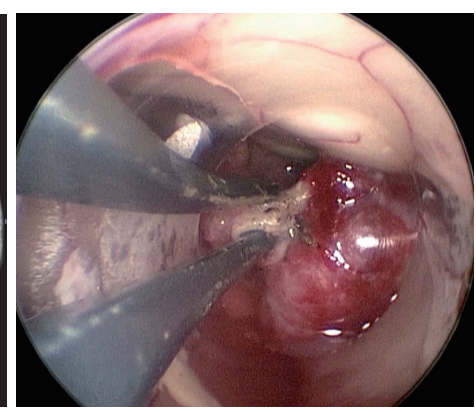

Fig. 6 A : Pre and post operative enhanced MRI of a 15-year-old boy with pleomorphic xanthoastrocytoma in the right lateral ventricle. Right; Endoscopic view after resection of the tumor in the wet field from right posterior horn puncture (Upper; right lateral, Lower; medial, Left; parietal, Right; caudal). The thalamus (star) is lateral to the choroid plexus (arrow).

B : Preoperative MRI showing an enhanced demarcated tumor in the left trigon in a 77-year-old woman (meningioma). Feeders from the anterior choroidal artery, and lateral posterior choroidal artery were coagulated using thin bipolar coagulators (Upper; left lateral, Lower; medial, Left; caudal, Right; parietal).

穿刺方向，つまりシースの向きが手術操作に影響を与え るので, 腫瘍の付着部位をなるべく正面からとらえるこ とができるようにバーホールの位置を考慮する。

大きな腫瘍では脳室の構造にひずみが生じる。腫瘍の 摘出後に構造が明らかになることがあるため, 正常構造 と疑われる組織は温存し, 不要な探索はせずに腫瘍のみ の摘出に徹する. Fig. $4 \mathrm{~A}$ に右前角正中側に付着した subependymoma の症例で腫瘍摘出前後の写真を示す. 腫 瘍によりモンロー孔は見えないが, anterior septal vein の走行からモンロー孔の位置は推測できる。裏の構造は できる限り観察を試み, 慎重に剝離する。

\section{側脳室体部}

上壁は脳梁体部，正中壁は透明中隔，側壁は尾状核， 下には正中から脳弓, 脈絡叢, 視床と並ぶ。モンロー孔 から透明中隔がなくなるポイントまでが体部と定義され ている。透明中隔の前縁は脳梁 rostrum, 後縁は脳梁と, 脳弓が合うポイントまで，前後ともになだらかに脳梁に
移行するので，その境界はわかりづらい．脳弓は視床の 形に沿って頭頂側にカーブし，後方に進むと脳梁に接近 し透明中隔が終わる。透明中隔がなくなると脳梁と脳弓 が接し，側脳室は外側へとカーブする。そのため脳室拡 大がなければ前角穿刺で同側の三角部を観察するのは困 難である．前角穿刺で対側の三角部へのアクセスは septostomy を介して可能である. Septostomy は腫瘍の手術 でも重要な手技であり，中隔の薄いポイントを見定める ことが重要である。多くの場合, anterior septal veinの すぐ後方で穿孔できる。透明中隔の前半部で中隔の動き を観察したり, 器具で触った時の動きを注意深く観察し, 穿孔すべきポイントを定める。 Trajectory の方向をよく 考慮して穿孔する方向を定める. 対側の脳弓を損傷しな いように注意する。中隔静脈は左右で走行部位は異なる ため，同側脳室側で静脈が走行していない部分でも反対 側に静脈が走行している場合があり，思わぬ出血に遭遇 する場合があるので注意する。

Thalamostriate vein は内視鏡脳室解剖において最も重 要な静脈であり，同定しやすい，モンロー孔から尾状核 

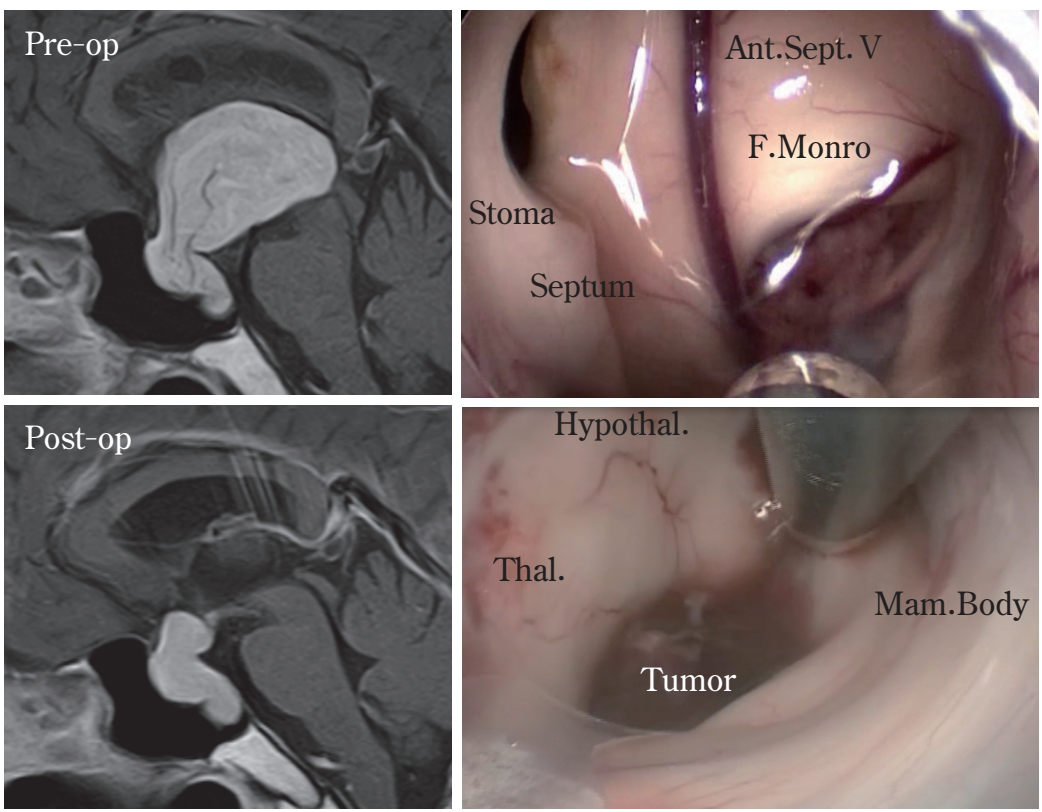

Fig. 7 Left: Pre and post operative MRI of a 49-year-old man with intra- and supra-sellar pituitary adenoma extending into the third ventricle without enlargement of the sellar. Two-stage tumor removal was performed. In the first surgery, a transparent sheath was inserted via the right frontal lobe, and the tumor inside the third ventricle was removed. In the second surgery, the tumor was totally removed by endonasal endoscopic approach.

Right upper: The tumor was removed through the foramen Monro by suction.

Right lower: Tumor in the third ventricle was removed except a small piece in the posterior part of the ventricle.

Ant.Sept.V : Anterior septal vein, F.Monro: Foramen Monro, Hypothal.: Hypothalamus, Thal.: Thalamus, Mam.Body: Mammillary body

と視床の間を走行し, posterior caudate vein が分枝して いる，腫瘍により脳室壁のひずみが生じていても，モン ロー孔が明らかになれば, thalamostriate vein の同定もほ ぼ確実にできる。またモンロー孔が変形して同定困難な 場合でも, 脈絡叢の走行を注意深くたどれば，モンロー 孔， thalamostriate vein を同定できる。多くの場合モン ロー孔外側で上衣組織下やや深く走行する部分があるの が特徴である. Thalamostriate vein は 2 本平行に走行す るバリエーションもある ${ }^{8)}($ Fig. 4B)。再発奇形腫の症例 で強い脳室変形を伴う例を Fig. 5 に示す。腫瘍の内容は 吸引可能な角質組織であり, 内減圧後の写真を図に示す。 右前頭部から穿刺し，ニューロポート使用. 同側のモン ロー孔は辺縁の形も判別できないほど拡大し, 対側モン ロー孔の形が確認できる.前交連が著しく引き延ばされ, 腫瘍内に迷入していたが，温存した。第三脳室は後下方 へ圧迫され, 内大脳静脈と脈絡叢が透見でき, 第三脳室 後半部では視床間橋と, 中脳水道が観察された（Fig. 5).

\section{側脳室三角部}

前壁正中側は crus of fornix，脈絡叢をはさんで外側は pulvinar であり，後角穿刺をすると，まず目の前にこの 構造が現れるはずである.さらに外側には尾状核があり, その外側は tapetum of corpus callosum となる. 正中側上 壁は bulb of corpus callosum があり，正中側下には calcar avis（鳥距）がある。下壁は medial に脳弓から続く hypocampus，lateral には collateral trigon（側副三角）が ある ${ }^{8)}$. Thalamus glioma の biopsy の時には必要な解剖で ある，後角穿刺は実際の内視鏡観察では脈絡叢が中央に 見えるだけで，確実なランドマークが脈絡叢しかない． 小さな上衣組織下の腫瘍はナビゲーションが必須である (Fig. 6). 


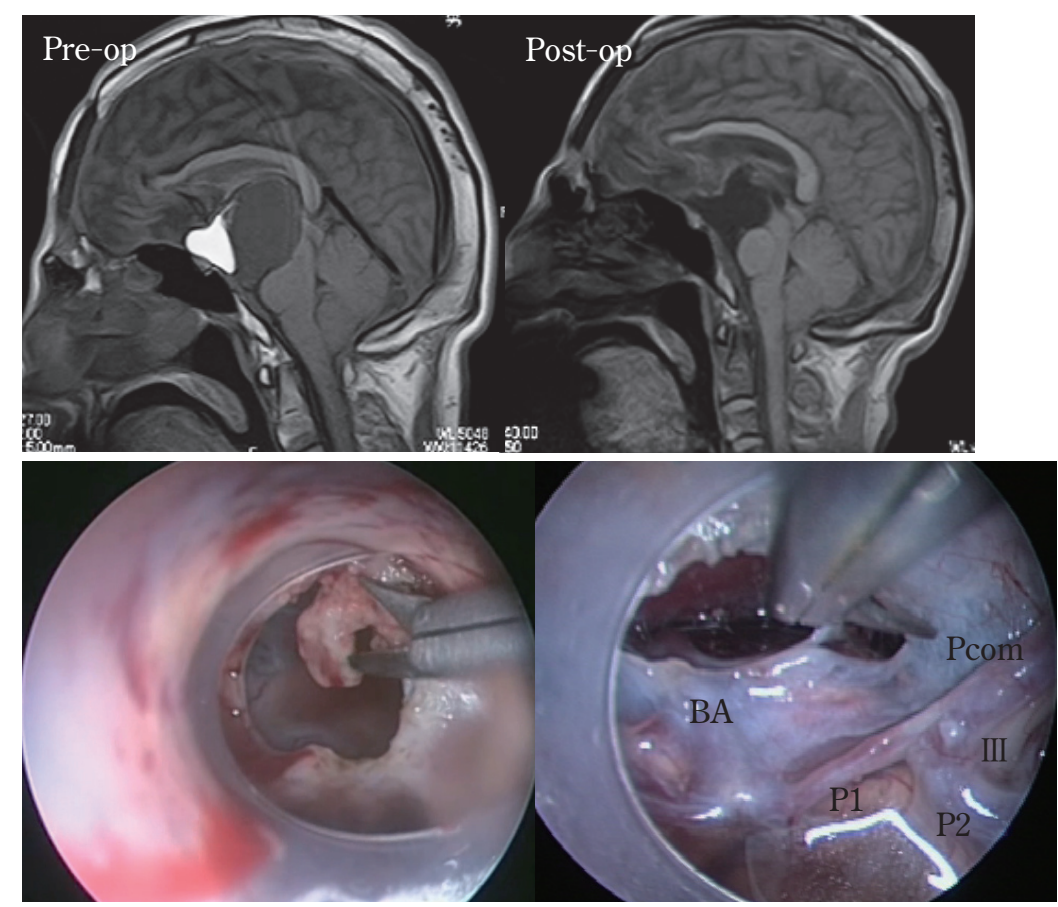

Fig. 8 Upper: Pre and post operative MRI of a 47-year-old man with a recurrent colloid cyst in the third ventricle. He underwent repeated surgeries to treat the cyst over the last 20 years.

Lower left: A transparent sheath was inserted into the foramen Monro, and the thick tough membrane of the colloid cyst was cut by scissors. Tough membrane at the bottom of the cyst was cut by the scissors sparing the vessels and nerves.

BA : Basilar artery, Pcom : Posterior communicating artery, III : Oculomotor nerve

\section{側脳室脈絡叢血管支配}

後角穿刺では脈絡叢球部 glomus が正面に観察され る。脈絡叢の栄養動脈は下角方向からは anterir choroidal artery, lateral posterior choroidal artery があり，体部 からは medial posterior choroidal artery がある.視床枕脈 絡叢部と外側膝状体は近接しており, lateral posterior choroidal artery の枝の虚血で視野障害が出現することが ある3)5).

\section{第三脳室}

上壁は脳弓, 2 層の脈絡膜とその間にある血管の層 (内 大脳静脈，内側脈絡叢動脈）で成り立つ. 第三脳室の上 壁を形成する 2 層の脈絡膜 (tela choroidea) に囲まれた空 間が velum interpositum であり, 多くはわずかな髄液の 存在する閉鎖腔である。第三脳室前壁は上端に左右の脳 弓と三角形を形成するように水平方向に前交連が存在す る. モンロー孔から前交連までの距離は 1.0 3.5 mm で,
術野では必ず脳弓の死角になり前交連は観察できないこ とがほとんどである．前交連，終板，視交叉で前壁を構 成する。下壁には視交叉, 漏斗樎凹, 灰白隆起, 乳頭体, 中脳水道がある。乳頭体と中脳水道の間は中脳の実質成 分で中脳被蓋にあたる。裏から見ると，視交叉，下垂体 柄, 灰白隆起, 乳頭体, 脚間後有孔質 (posterior perforating substance）がある ${ }^{8)}$. 後壁は中脳水道，後交連， 松果体陥凹，手綱交連で構成される。側壁は前下方が視 床下部，上部は視床である。

顕微鏡手術の第三脳室への手術アプローチはさまざま な方法が報告されているが，内視鏡のアプローチでは， その特性から，自然孔であるモンロー孔を経由する方法 が基本となる。しかし，モンロー孔の損傷は避けなけれ ばならない．特に両側からのアプローチを行う場合は, わずかな損傷でも高次脳機能の影響が出る場合があるの で注意が必要である。凝固操作を行う場合は必ずシース で脳弓の保護に努める必要がある。側脳室の手術に比心゙ シースの可動性が限られるので, 手術操作に制限がある. 現状ではモンロー孔が拡大した症例，もしくはサイズに 
合わせた細径のシースによる限られた手技で行う手術を 行っている。病変により変形した第三脳室はモンロー孔 の拡大があり, two-hand surgery が可能である（Fig. 7). 第三脳室底は周辺構造物を圧迫し, 変形しているので, 重要構造の同定が重要である（Fig. 8).

\section{結 語}

内視鏡下脳室内腫瘍摘出術の概要，内視鏡手術におけ る脳室解剖について述べた。低侵襲で深部観察に優れた 内視鏡は, 脳室内腫瘍に対する手術に有効な手段である. 機器の発展, 技術の進歩により今後手術適応も広がると 考えられる。しかし, 安全な手術を行うためには, 術前 の解剖学的検討が必須である，条件がそろえば，低侵襲 で有効な内視鏡手術を行うことができるが, 傍脳室の重 要構造物はわずかな損傷でも症状を呈する場合があり, 愛護的に操作しなければならないため, 術前検討で適応 を慎重に決断する必要がある。脳室内腫瘍の手術は全摘 出のみが目的ではない. 手術の目的を明確にし, 腫瘍が 予想外に硬い場合, 出血のコントロールが困難な場合な ど，さまざまな場面を想定し，手術中にシースのサイズ を変えたり，顕微鏡手術に切り替えることも含め計画を 立てるべきである。また，太いシースを使用した場合， trajectory を介した髄液の貯留により術後の subdural effusion がまれに重篤な合併症を引き起こすことも忘れ てはならない4)9).

\section{文 献}

1) Harris $\mathrm{AE}$, Hadjipanayis $\mathrm{CG}$, Lunsford $\mathrm{LD}$, Lunsford $\mathrm{AK}$, Kassam $\mathrm{AB}$ : Microsurgical removal of intraventricular lesions using endoscopic visualization and stereotactic guidance. Neurosurgery $\mathbf{5 6}: 125-132,2005$.

2) Kassam AB, Engh, JA, Mintz AH, Prevedello DM: Completely endoscopic resection of intraparenchymal brain tumors. J Neurosurg 110: 116-123, 2009.

3) Marinković S, Gibo H, Milisavljević M, Djulejić V, Jovanović VT: Microanatomy of the intrachoroidal vasculature of the lateral ventricle. Neurosurgery 57:22-36, 2005.

4) Morita A, Kelly PJ : Resection of intraventricular tumors via a computer-assisted volumetric stereotactic approach. Neurosurgery 32: 920-927, 1993.

5) Neau JP, Bogousslavsky J: The syndrome of posterior choroidal artery territory infarction. Ann Neurol 39: 779-788, 1996.

6) Nishihara T, Teraoka A, Morita A, Ueki K, Takai K, Kirino $\mathrm{T}: \mathrm{A}$ transparent sheath for endoscopic surgery and its application in surgical evacuation of spontaneous intracerebral hematomas. Technical note. J Neurosurg 92: 10531055, 2000.

7) Recinos PF, Raza SM, Jallo GI, Recinos VR: Use of a minimally invasive tubular retraction system for deep-seated tumors in pediatric patients. J Neurosurg Pediatr 7: 516521, 2011.

8) Rhoton AL Jr: The supratentorial cranial space: microsurgical anatomy and surgical approaches. Chapter 5 , The lateral and third ventricles. Neurosurgery $\mathbf{5 1}$ (Supple 1) : 207-272, 2002.

9) Tanaka Y, Sugita K, Kobayashi S, Takemae T, Hegde AS : Subdural fluid collections following transcortical approach to intra- or paraventricular tumours. Acta Neurochir (Wien) 99:20-25, 1989.

\section{脳室内および脳室近傍腫瘍摘出に必要な内視鏡手術解剖}

\section{渡邉 督 永谷 哲也 齋藤 清}

脳室内腫瘍に対する内視鏡下腫瘍摘出術, 脳室の内視鏡解剖について解説する. 明るく広い視野角 で深部病変を近接して観察できる点, wet field で観察できる点が内視鏡手術の利点である．また，視 点の動きにより立体的な把握が比較的しやすい. シースを介して專用の器具を用い, 内視鏡単独手術 による腫痬摘出が可能である. 脳室は腫瘍によりしばしばひずみが生じオリエンテーションが難しく なるが, 側脳室の構造を理解し，モンロー孔，眽絡叢, thalamostriate vein などの限られたランドマー クを基準に注意深く観察すれば解剖を把握できる. 脳室は温存すべき重要構造物に囲まれており，わ ずかな損傷でも症状を呈するため慎重な手術操作を要する. 